\title{
Study of the Iodine Content in Table Salt of Kitchen during the Period of Conservation
}

\author{
Diaby Vandjiguiba ${ }^{1 *}$, Gnonsoro Urbain Paul ${ }^{2}$, Ake Assi Yolande ${ }^{1}$, Koffi Kouamé Mathias ${ }^{1}$, Sanogo Isiaka ${ }^{1}$, Yapo Adou \\ Francis $^{3}$, Ardjouma Dembele ${ }^{2}$ \\ ${ }^{1}$ Central laboratory for the food hygiene and Agricultural Processing Industry, LANADA, Ministry for Agriculture and the Rural Development, 04 BP \\ 612 Abidjan 04 \\ ${ }^{2}$ Central laboratory of Agrochemicals and Ecotoxicology (LCAE), LANADA, 04 BP 612 Abidjan 04, Côte. d'ivoire \\ ${ }^{3}$ Laboratory of Pharmacodynamics-Biochemical, UFR Biosciences, University FELIX Houphouët Boigny-Abidjan (Côte.d'ivoire), 22 BP 582 Abidjan \\ 22
}

\author{
Article History \\ Received: 06.12.2020 \\ Accepted: 18.12 .2020 \\ Published: 25.12.2020
}

Journal homepage:

https://www.easpublisher.com

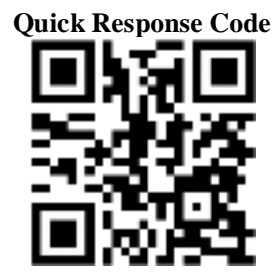

Abstract: The adequately iodized salt consumption is significant in the prevention and the fight against the disorders due to the iodine deficiency (TDCI). The objective of this study was to evaluate the iodine content of cooking salts in the households, in order to assess its quality during the conservation. With this intention, a taking away of $500 \mathrm{G}$ table salt was carried out trades about it and preserved under the conditions imitating that of the households. The results obtained showed a loss of iodine during its conservation. Indeed, of the first week at the fifth week of conservation, salt recorded a significant loss of its iodine content of $12,67 \mathrm{ppm}$ is $21,71 \%$ of its starting iodine content. This work suggests that salt must be consumed as soon as possible to avoid an exposure to an iodic deficiency of the population.

Keywords: Salt, iodine, TDCI, goitre, stupidity.

Copyright (C) 2020 The Author(s): This is an open-access article distributed under the terms of the Creative Commons Attribution 4.0 International License (CC BY-NC 4.0) which permits unrestricted use, distribution, and reproduction in any medium for non-commercial use provided the original author and source are credited.

\section{INTRODUCTION}

Iodine is micronutriment essential to the organization [1]. It is a fundamental substance with the development of the thyroid hormones. Its contribution is primarily food and it is enough to small quantities between 100 to $200 \mu \mathrm{g}$ per day. The iodine deficiency remains a major threat for the health and the development of the populations of the whole world [2]. The disorders caused by the iodine deficiency are many and well-known [3]. In Western and Central Africa, 250 million people are likely to present disorders due to the iodine deficiency (TDCl) which are the endemic goitre, the hypothyroïdie, the stupidity, the insufficiency of the function of reproduction, the infant mortality, the delay of growth, etc In Côte.d'ivoire, the zones most touched by the iodine deficiency are the mountainous areas of the Mid-west and those of the high plateaus of North [4]. In the world, the iodine deficiency occupies a particular place among the deficiencies in micronutriments which pose today a major problem of public health [5].Thus, WHO recommends the universal iodation of salt like strategy of prevention and control of the TDCI since 1994 [6, 7]. With this intention, the representatives of the industry of salt and the principal partners in the field of the fight against the disorders due to the iodine TDCI deficiency agreed at The Hague in June 2000 to work together in favour of the elimination of the TDCI [5].

The Ivory Coast is one of the countries which adhered to the strategy of universal iodation salt to prevent and control the disorders due to the iodine deficiency [4]. In spite of these visible efforts, goitreuse pathology remains in Côte. d'ivoire a major problem of public health because several tests control allowed to affirm its endemicity [8]. Salt is the ideal vehicle of the daily iodine contribution for the populations because it is an essential food. It can provide a constant daily ration of iodine to lower cost [4], it périme not and it is moderately consumed [9]. However, iodine is it stable during the conservation in the households? The objective of this study was to evaluate the iodine content in cooking salt and its kinetics during the conservation. 


\section{Material and Methods \\ Sampling Technique}

A taking away of $500 \mathrm{~g}$ table salt was taken in the trade and was preserved at the laboratory under the conditions of conservation imitating those of the households. The content was evaluated during 5 weeks because of 15 proportionings per week is three analyses per day. These samples were analyzed quantitatively at the Central Laboratory for the Food hygiene and Agricultural processing industry (LCHAI), technical unit of the National Laboratory of Support to the Agricultural Development (LANADA), by iodometric titration according to standard of the Ivory Coast $\mathrm{N}$ Ni:03 09003.

\section{Method of determination of the iodine content by iodometry \\ Procedure \\ Beforehand dried and cooled, $10 \mathrm{~g}$ of salt were} weighed. Using a conical flask, these $10 \mathrm{~g}$ of salt were dissolves in $50 \mathrm{ml}$ of distilled water. The unit thus obtained was homogenized to which was added $1 \mathrm{ml}$ of potassium iodide solution $10 \%$ and $1 \mathrm{ml}$ of acetic acid solution. The solution transfers with the yellow, this color progressively develops release of molecular iodine during approximately $10 \mathrm{~min}$ until it finishes.

The reaction was then titrated with the sodium thiosulfate solution $(0,002 \mathrm{~N})$ until disappearance of yellow colouring. After the addition of $5 \mathrm{ml}$ of starch solution with $1 \%$, a blue colouring indicating the presence of molecular iodine in the solution appears. Titration was continued until disappearance of this colouring and $\mathrm{V}$ the total volume used for titration was noted.

The expression of the results was given according to the formula: Iodize $(\mathrm{ppm})=\mathrm{V} \mathrm{X} \mathrm{4,} 2332$. Where $\mathrm{V}$ is the volume of sodium $0,002 \mathrm{~N}$ Thiosulfate having been used for titration. The quality standard was fixed while following the instructions of the standard to knowing:

- [30-50] ppm for the iodine content in the households and the sales in detail. Salts of content lower or higher than this standard were regarded as not-in conformity.

\section{Modelisation of thestudy}

The objective was to know if, in a general way, the time of conservation of salt has an influence on the iodine content. The goal is to explain as well as possible how the iodine content varies according to time and if required to predict this content as from time [10].

\section{Statistical Analysis}

Statistical tests grapPhad.Prism.V5.01. and Ms-Excel were used for the data processing. The data were analyzed with ANOVA One-Way. The nonparametric test of Turkey was used for the comparison of the variance of the values obtained. Also, the statistical column was used for the determination of the averages and standard deviations. The difference between two variances was significant, if $p<0,05$. The linear straight regression line was given.

\section{RESULTS}

Figure 1, below, assembles the variation of the iodine content during the conservation. This variation is accentuated by a significant fall $(\mathrm{p}<0.0001)$ of the iodine content according to the time of conservation. Thus, at the first week, this content which was of 57, 99 $\pm 2,45 \mathrm{ppm}$, significantly decreased with $52,43 \pm 2,44$ ppm at the second week. As for the third week, this content further decreased significantly to compared give $49,96 \pm 1,52 \mathrm{ppm}$ to the starting content. It was in the same way at the fourth week when it was given to record a content of 49,65 $\pm 1,98 \mathrm{ppm}$. At the fifth week of conservation, the iodine content respectively reached $45,32 \pm 2,19 \mathrm{ppm}$. First week at the fifth week of conservation, salt recorded a significant loss of its iodine content of $12,67 \mathrm{ppm}$ is $21,71 \%$ of its starting iodine content.

The line of equation $y=-3,212 x+59,906$ is the straight regression line estimated of the iodine content over the time of conservation (Figure 2) with $\mathrm{R}^{2}$ $=0,9361$ watch a strong correlation between the variable to be predicted (iodine content) and the time of conservation (variable prédictible).The directing coefficient of the right-hand side being negative shows that the curve is decreasing, which symbolizes the loss of iodine. This modeling starting from the equation showed that in 18 weeks and 2 days, iodine disappears food salt completely. 


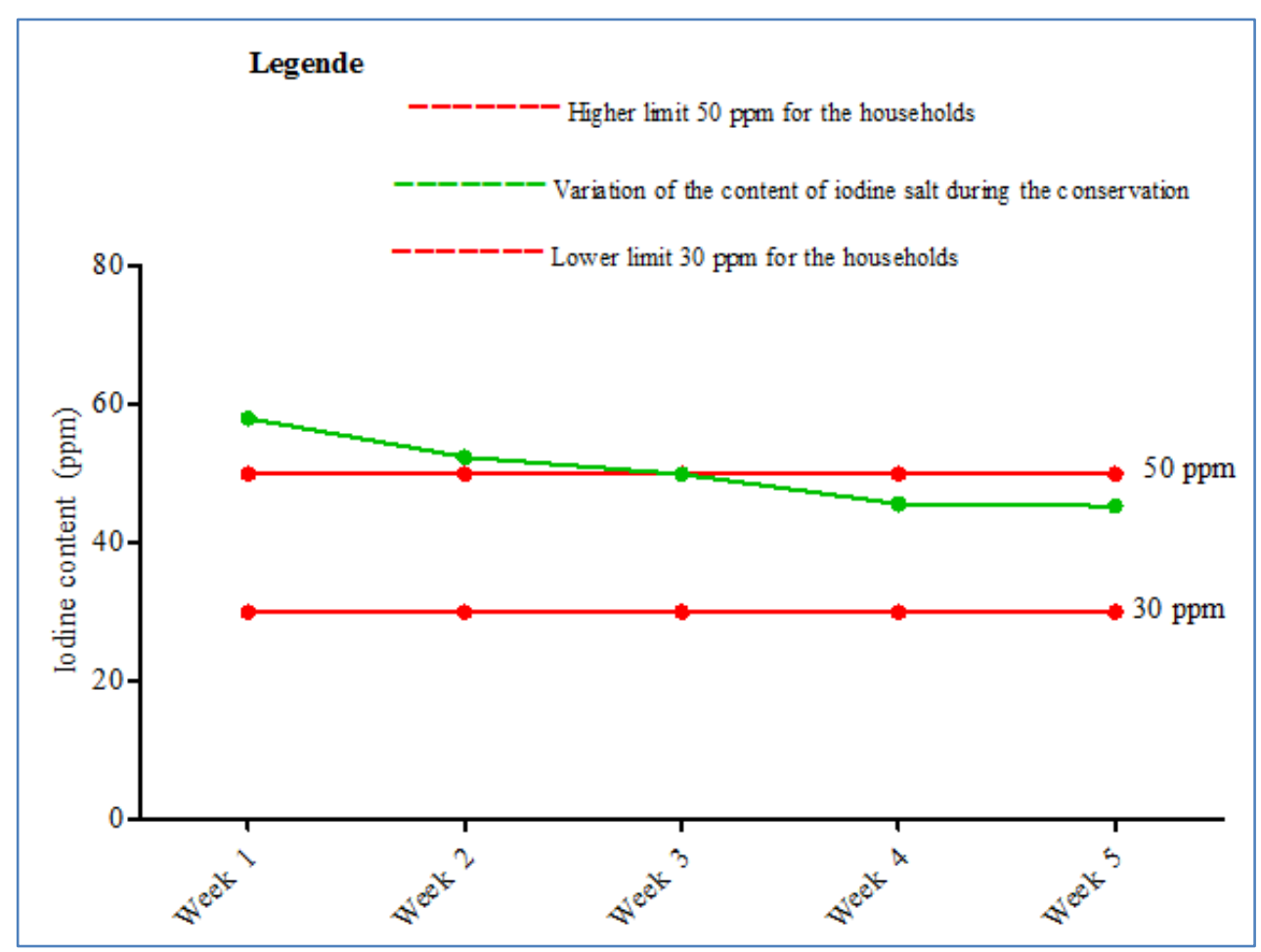

Fig-1: Variation of the iodine content during the conservation according to time

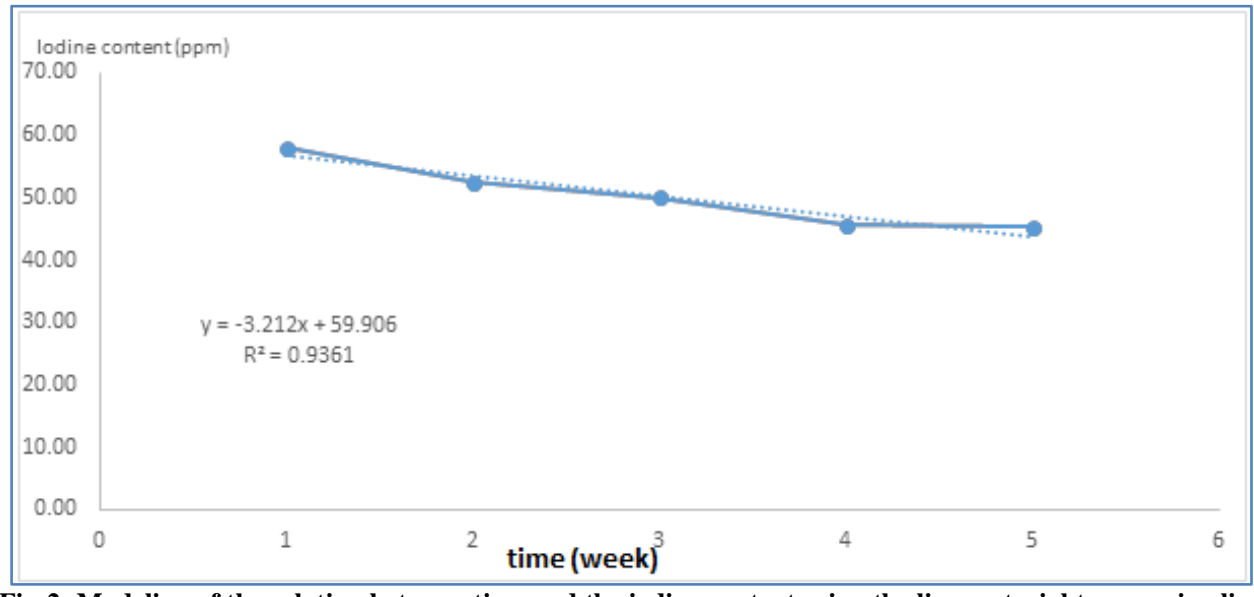

Fig-2: Modeling of the relation between time and the iodine content using the linear straight regression line

\section{DisCUSSION}

The recommendations suggest that the structures responsible for the food and the nutrition must take care that more than $90 \%$ of the households has access to adequately iodized salt i.e. containing 15 to $40 \mathrm{ppm}$ of iodine for the benign one $[6,7]$ and 30 to 50 iodine ppm for Côte d'ivoire (Ni:03 09 003).

These recommendations used to evaluate the adequate content iodine are thus different from a country with another [7]. The countries do not have necessarily the same minimum threshold for the iodation of salt (the minimum necessary for the universal iodation of salt is of $15 \mathrm{ppm}$, but certain countries use $20 \mathrm{ppm}$ [11].

In the study carried out, the results obtained showed a significant fall of the iodine content of salt during its conservation. First week at the fifth week of conservation, salt recorded a significant loss of its iodine content of $12,67 \mathrm{ppm}$ is $21,71 \%$ of its starting iodine content. This iodic decomposition of salt can be explained by the impurities, moisture, granulometry, the mode and the shelf life according to DJONGA et al. [3]. Other factors can explain this fall of iodine in particular the chemical form of enrichment, bad conditioning, the exposure to bad weather [12]. The work completed in the present study is similar to those of SEID and al, [13] which noted an iodine loss of 6, $66 \mathrm{ppm}$ is $4,73 \%$ of the starting content (140,85ppm).According to these authors, the loss would be related on the granulometry of the crystals and the presence of the insoluble matters.

In the markets, the salts exposed to the free air in basins, are more prone to the loss of iodine considering their mode of conditioning. Indeed, 
according to GOMINA et al., [6], the cooking salts stored in the plastic sachets have an average content iodizes some weaker than that of salts in the bottles out of glass. Moreover, the percentage of iodine loss in salt increases with the size of grain [6].

That would thus have become the iodine contained in salt at the end of six to twelve months of storage? With this question of SEID et al. [13], it was elaborate in this study, a modeling of the loss of iodine in time. According to this modeling, iodine disappears completely in only 4 months two weeks. Thus the iodine content of imported salt or product in factory was fixed between 50 and $80 \mathrm{ppm}$. The enrichment of salt out of iodine consequently must be the object of a rigorous control, one duration and a mode of adequate conservation in order to guarantee an iodine contribution sufficient for population $[14,15]$.

\section{CONCLUSION}

The study carried out showed a loss of iodine in table salt during its conservation. This loss was of $12,67 \mathrm{ppm}$ is $21,71 \%$ of its starting iodine content in only 5 weeks. This work suggests that salt as well as other products nouveau riches out of iodine must be consumed as soon as possible to avoid the exposure to an iodic deficiency. It would be appropriate that the industrialists of the sector respect the policy of iodation and set up one efficient duration of consumption of iodized food.

\section{REFERENCES}

1. Menon, K., \& Skeaff, S. (2016). Iodine: Iodine deficiency disorders (IDD). Reference Module in Food Science, from Encyclopedia of Food and Health, 437-443.

2. Gunnarsdottir, I., \& Dahl, L. (2012). Iodine intake in human nutrition: a systematic literature review. Food \& nutrition research, 56(1), 19731.

3. Djonga, O., Mahamat, M. A., Bessane, C., Danama, K. A., \& Boy, O. B. (2012). Comportements alimentaires et carence en iode. Mali Medical, 27(4), 1.

4. Adou, P., Aka, D., Aké, M., Koffi, M., Tébi, A., \& Diarra-Nama, A. J. (2002). Evaluation de la teneur en iode du sel alimentaire à Abidjan (Côte d'Ivoire). Cahiers d'études et de recherches francophones/Santé, 12(1), 18-21.

5. de Benoist, B., \& Delange, F. (2002). La carence iodée: bilan et perspectives pour le futur. Cahiers

d'études et de recherches
francophones/Santé, 12(1), 9-17.

6. Assoumanou, M. G., Zohoncon, T. M., \& Akpona, S. A. (2011). Evaluation de la teneur en iode des sels de cuisine dans les ménages de deux zones d'endémie goitreuse du Bénin. International Journal of Biological and Chemical Sciences, 5(4), 1515-1526.

7. Mizéhoun-Adissoda, C., Yémoa, A., Jerome, C. S., Biobou, A., Alouki, K., Azandjèmé, C., ... \& Desport, J. C. (2018). Teneur en iode et qualité microbiologique des sels alimentaires commercialisés au Bénin. Nutrition clinique et métabolisme, 32(2), 102-108.

8. Kouamé, P., Ouattara, H., \& Bellis, G. (2015). La carence en iode chez les enfants de glanle, un village de l'Ouest de la Côte d'Ivoire: Une urgence silencieuse. Rev Ivoir Sci Technol, 26, 245-253.

9. McNeil, D. G., \& Donald, G. (2006). In Raising the World's IQ, the Secret's in the Salt. New York Times, 16.

10. Regmi, H. R., Rijal, K., Joshi, G. R., Sapkota, R. P., \& Thapa, S. (2019). Factors Influencing Food Insecurity in Nepal. Journal of Institute of Science and Technology, 24(2), 22-29.

11. Horton, S., \& Miloff, A. (2010). Iodine status and availability of iodized salt: an across-country analysis. Food and nutrition bulletin, 31(2), 214220.

12. Banza, B. I., Lumbu, J. B. S., Donnen, P., Twite, E. K., Kwete, D. M., Kazadi, C. M., ... \& Robert, A. (2016). La teneur en iode du sel de cuisine consommé à Lubumbashi et le statut iode des personnes vulnérables: cas de femmes enceintes de milieux défavorisés. The Pan African Medical Journal, 23.

13. Ali, M. S., Tidjani, A., \& Ayessou, N. C. (2015). Etude de la stabilité de l'iode dans le sel iodé. International Journal of Biological and Chemical Sciences, 9(5), 2719-2734.

14. Luo, Y., Kawashima, A., Ishido, Y., Yoshihara, A., Oda, K., Hiroi, N., ... \& Suzuki, K. (2014). Iodine excess as an environmental risk factor for autoimmune thyroid disease. International journal of molecular sciences, 15(7), 12895-12912.

15. Mizéhoun-Adissoda, C., Agueh, V., Yemoa, A., Sègla, B. I., Alihonou, F., Jossè, R. G., ... \& Desport, J. C. (2016). Évaluation de la teneur en iode des sels alimentaires dans les communes de Glazoué et deOuidah (Bénin) et comparaison aux recommandations. Nutrition clinique et métabolisme, 30(1), 38-44. 